\title{
Pozycja pokrzywdzonego na tle przepisów materialnego prawa wykroczeń
}

\begin{abstract}
The aim of this work is to establish to what extent discrepancies of substantive misdemeanour law (relating to criminal law), which stem from simplification of responsibility rules, impact the position of victim. There are no general rules and principles relating to formation of the position of victim in either criminal law or misdemeanour law. Only by analysing particular regulations of the both respective codes allows one to reconstruct the status of victim and confronting it on the plain of the two responsibility regimes in question. The said confrontation reveals far-reaching differences within the scope of victim's position in substantive regulations of misdemeanour law, some of which weaken the victim's position, while other - strengthen it. Although those differences vary to their weight, yet it seems that regulations restricting the presence of the figure of victim are more significant - they genuinely decrease the competence of a person to whom the harm was made. Amongst the said regulations, first and foremost, have to be counted those that relate to possibility of ruling compensatory penal measures, as well as regulations defining the periods of limitation (aside from other discussed regulations). The assumed dual model of responsibility within this scope, in some cases, compromises the principle of equality before the law enshrined in Article 32 paragraph 1 of the Constitution of the Republic of Poland.
\end{abstract}

Keywords: victim, misdemeanour, equality before the law, the responsibility rule

I. Materialne prawo wykroczeń nazywane jest młodszą siostrą prawa karnego lub małym prawem karnym. Mimo bardzo znaczących podobieństw do prawa karnego wiele instytucji lub konstrukcji w prawie wykroczeń w ogóle nie występuje lub ma dość uproszczoną budowę albo ograniczony zasięg. Takie rozwiązania powodują, że sytuacja m.in. pokrzywdzonego w materialnym prawie wykroczeń jest istotnie różna od sytuacji pokrzywdzonego w materialnym prawie karnym. 
W nauce prawa procesowego można znaleźć kilka publikacji odnoszących się do pokrzywdzonego w prawie wykroczeń, dotyczą one jednak zakresu jego uprawnień procesowych ${ }^{1}$. Natomiast w niniejszej publikacji chciałabym zająć się zasadniczo aspektami prawnomaterialnymi.

Analogicznie do prawa karnego definicja pokrzywdzonego została umieszczona $\mathrm{w}$ przepisach proceduralnych. Ponieważ rozwiązanie przyjęte $\mathrm{w}$ procesowym prawie wykroczeń jest $\mathrm{w}$ dużym stopniu recepcją przepisu art. 49 k.p.k., aktualizują się również ogólne uwagi autorów podejmujących zagadnienia związane $\mathrm{z}$ pokrzywdzonym $\mathrm{w}$ procesie karnym. I tak K. Dudka zauważa, że ustawowa definicja pokrzywdzonego wyznacza krąg podmiotów uprawnionych do uczestnictwa w procesie karnym $\mathrm{w}$ tym charakterze oraz prowadzi - w efekcie - do ograniczenia liczby pokrzywdzonych przestępstwem, pozbawiając organy procesowe możności swobodnego decydowania o tym, kto może być uznany za pokrzywdzonego w procesie karnym ${ }^{2}$. Natomiast C. Kulesza konstatuje, że ustawowa definicja pokrzywdzonego pełni funkcję gwarancyjną, stanowi bowiem punkt wyjścia do efektywnej realizacji uprawnień pokrzywdzonego w procesie karnym ${ }^{3}$.

Zgodnie z treścią przepisu art. 25 kodeksu postępowania w sprawach o wykroczenia (k.p.w.) ${ }^{4}$ pokrzywdzonym jest ten, czyje dobro prawne zostało bezpośrednio naruszone lub zagrożone przez wykroczenie. Nie ma przy tym wątpliwości, że mimo braku rozróżnienia pokrzywdzonego jako osoby fizycznej lub osoby prawnej albo jednostki organizacyjnej, tak jak to czyni przepis art. 49 k.p.k., z uwagi na fakt, iż ustawodawca użył określenia „ten”, przyjąć należy, że pokrzywdzonym jest więc oprócz osoby fizycznej lub prawnej także instytucja państwowa, samorządowa i społeczna, choćby nie miała osobowości prawnej ${ }^{5}$ (co potwierdza odesłanie do przepisu art. 51 k.p.k. - art. $25 \S 3$ k.p.w.). Jak puentuje to K. Mamak,

${ }^{1}$ J. Lewiński: Pokrzywdzony $w$ postępowaniu $w$ sprawach o wykroczenia. Pal. 2003, nr 11-12; S. STACHOWIaK: Podstawowe uprawnienia pokrzywdzonego w ujęciu nowego kodeksu postępowania $w$ sprawach o wykroczenia. PPol. 2002, nr 3-4; B. WójcicкA: Pozycja pokrzywdzonego $w$ nowym kodeksie postępowania $w$ sprawach o wykroczenia. PiP 2001, nr 10; C. Kulesza: Ewolucja uprawnień pokrzywdzonego $w$ polskim prawie karnym. W: $Z$ problematyki wiktymologii. Księga dedykowana Profesor Ewie Bieńkowskiej. Red. L. MazowIECKA, W. Klaus, A. TaRWacka. Warszawa 2017, s. 77 i nast.

${ }^{2}$ K. DudKa: Skuteczność instrumentów ochrony praw pokrzywdzonego w postępowaniu przygotowawczym $w$ świetle badań empirycznych. Lublin 2006, s. 35. Zob. też uchwałę SN I KZP 45/05.

${ }^{3}$ C. Kulesza: Rola pokrzywdzonego $w$ procesie karnym $w$ świetle ustawodawstwa i praktyki wybranych krajów zachodnich. Białystok 1995, s. 26.

${ }^{4}$ Dz.U. 2001, nr 106, poz. 1148.

5 W. KotowsKI, B. KuRZĘPA: Kodeks postępowania w sprawach o wykroczenia. Komentarz. Warszawa 2016, s. 146. 
użycie zwrotu „ten” oznacza, że procedura nie wyklucza żadnego podmiotu, który może być pokrzywdzony wykroczeniem ${ }^{6}$.

Jak wskazują W. Kotowski i B. Kurzępa, aby dany podmiot uzyskał status pokrzywdzonego, jego dobro prawne musi być zagrożone lub naruszone przez wykroczenie w sposób bezpośredni, a to oznacza, że między czynem a naruszeniem lub zagrożeniem dobra nie może być żadnych ogniw pośrednich ${ }^{7}$. Ponadto dla ustalenia zakresu tego sformułowania sięgnąć należy do przepisów prawa materialnego. To poszczególne typizacje operują pojęciem dobra prawnego (utożsamianego $\mathrm{z}$ indywidualnym przedmiotem ochrony), którego naruszenie lub narażenie (czy: zagrożenie jak stanowi przywołany przepis) jest podstawą odpowiedzialności za wykroczenie. W literaturze przedmiotu dość powszechnie podkreśla się, że pojęcie pokrzywdzonego - przez pryzmat sformułowania „bezpośredniego naruszenia dobra prawnego" - interpretować należy dość wąsko, uznając, iż pokrzywdzonym jest wyłącznie osoba, której dobro stanowi tzw. indywidualny (bliższy lub dalszy) przedmiot ochrony ${ }^{8}$. W tym duchu wypowiedział się w 2003 r. SN ${ }^{9}$, uznając, że w sprawie o przestępstwo z art. $241 \S 1$ k.k. osoba, której dotyczą ujawnione okoliczności, jest pokrzywdzona w rozumieniu art. 49 § 1 k.p.k. tylko wtedy, gdy czyn ten jednocześnie wyczerpuje znamiona określone w innym przepisie karnym, którym to przestępstwem lub przestępstwem współukaranym jej dobro prawne zostało bezpośrednio naruszone lub zagrożone. W uzasadnieniu tej uchwały SN podniósł, że inna interpretacja stanowiłaby odejście od w miarę wyrazistego kryterium przedmiotu ochrony konkretnego przepisu prawa karnego materialnego i odwołanie się do znacznie mniej konkretnych względów słusznościowych. Dlatego też w uchwale tej SN krytycznie odniósł się do postanowienia SN z 2002 r. ${ }^{10}$, w którym uznał za dopuszczalny status pokrzywdzonego osoby będącej stroną w postępowaniu określonym w $§ 1$ art. 233 k.k. D. Świecki, powołując się na uchwałę

${ }^{6}$ K. Mamak. W: Kodeks postępowania w sprawach o wykroczenie. Komentarz. Red. A. SAKowicz. Warszawa 2018, s. 157.

7 W. KotowsKI, B. KuRZĘPA: Kodeks postępowania w sprawach o wykroczenia. Komentarz. Warszawa 2016, s. 146.

8 Por. np. Z. Gostyński, R.A. Stefański. W: Kodeks Postępowania Karnego. Komentarz. T. I. Red. Z. GostYŃsKI. Warszawa 2003, s. 425-426. Szerzej o ustalaniu i znaczeniu bliższego i dalszego przedmiotu ochrony dla wyznaczenia zakresu pojęcia „pokrzywdzony" zob. K. Мамак. W: Kodeks postępowania w sprawach o wykroczenie. Komentarz. Red. A. SAKowicz. Warszawa 2018, s. 157-158.

${ }_{9}$ Uchwała SN z dnia 21 października 2003 r., I KZP 29/03. OSNKW 11-12/2003, poz. 94 .

${ }_{10}$ Postanowienie SN z dnia 23 kwietnia 2002 r., I KZP 10/02. PiP 2002, nr 7-8, poz. 1. 
SN z 1999 r. $^{11}$, stwierdza, że pojęcie pokrzywdzonego relatywizuje się jedynie do zespołu znamion czynu będącego przedmiotem postępowania lub czynów współukaranych, dodając, że dobro prawne, które zostało naruszone lub zagrożone przez wykroczenie, może być głównym lub pobocznym przedmiotem ochrony ${ }^{12}$. Warto jednak zaznaczyć, że w $1976 \mathrm{r}$. SN sformułował pogląd, ,że chociaż kryterium uznania jakiejś osoby za pokrzywdzoną wynika z prawa karnego materialnego, to nie oznacza jednak, by organ procesowy pozbawiony był możliwości dokonywania odmiennej oceny dowodów także co do przyjętego uprzednio założenia, że dana osoba jest pokrzywdzona przestępstwem. O tym bowiem, kto jest osobą pokrzywdzoną w konkretnej sprawie, decyduje dobro prawne tej osoby naruszone lub zagrożone przez sprawcę czynu, i to w sposób bezpośredni (art. 40 § 1 k.p.k.), choćby nie wynikało to wprost z opisu tego czynu i jego kwalifikacji prawnej. Owa bezpośredniość wchodzi w grę także wtedy, gdy przedmiotem ochrony prawnej jest wprawdzie dobro ogólniejszej natury, ale zagrożenie tego dobra powoduje również bezpośrednie pokrzywdzenie indywidualnej osoby"13. Wydaje się, że problem ten nabiera szczególnego znaczenia $\mathrm{w}$ prawie wykroczeń, ponieważ zasadnicza większość typizacji jest czynami z narażenia abstrakcyjnego, a co za tym idzie, do ustawowych znamion nie należy dobro zindywidualizowanego podmiotu. Na gruncie prawa wykroczeń ilustracją tego rodzaju problemów może stać się przepis art. 68 k.w., wprowadzający karalność m.in. za wyrabianie pieczęci bez właściwego zamówienia. Pojawia się bowiem pytanie, czy podmiot, w imieniu którego pieczęć została bezprawnie wykonana, może uzyskać status pokrzywdzonego. Idąc tokiem myślenia zaprezentowanym przez SN we wspomnianej uchwale z 2003 r., można by rozważać, czy osoba, która ucierpiała w kolizji samochodowej, jest pokrzywdzonym wykroczeniem opisanym w przepisie art. 86 k.w., skoro przedmiotem ochrony jest bezpieczeństwo i porządek w komunikacji, co oczywiście stanowi ostatecznie wykładnię contra legem i jest sprzeczne $\mathrm{z}$ intuicyjnym rozumieniem pokrzywdzenia.

Niezależnie od poczynionych uwag stwierdzić należy, że rola pokrzywdzonego w prawie wykroczeń ma mniejsze znaczenie niż w prawie karnym, w tym sensie, że konstrukt pokrzywdzonego występuje o wiele rzadziej w przepisach materialnego prawa wykroczeń. Pokrzywdzony występuje bowiem de facto $\mathrm{w}$ wykroczeniach $\mathrm{z}$ naruszenia dobra materialnego względnie zindywidualizowanych osób i wykroczeniach z narażenia

11 Uchwała SN z dnia 15 września 1999 r., I KZP 26/99. OSMKW 11-12/1999, poz. 69.

12 D. ŚwIEcKI: Metodyka pracy sędziego w sprawach o wykroczenia. Warszawa 2012, s. 32.

13 Uchwała SN Izby Karnej oraz Wojskowej z dnia 26 listopada 1976 r., VI KZP 11/75. OSNKW 1/1977, LEX nr 19212. 
konkretnego. Natomiast wykroczenia z narażenia abstrakcyjnego rodzić będą wspomniane wyżej wątpliwości co do możliwości uznania za pokrzywdzonego osoby, która odniosła szkodę lub krzywdę zabronionym zachowaniem.

Z tego też względu skonstruowanie katalogu wykroczeń zamieszczonych w kodeksie wykroczeń, w których jest miejsce dla figury pokrzywdzonego, może być nieco utrudnione. Bez wątpienia znajdą się tu wszystkie te wykroczenia, których ściganie następuje - bezwzględnie lub na zasadzie wyjątku - na żądanie pokrzywdzonego. Uzupełnienie tej listy o inne wykroczenia może już sprawić kłopot i rodzić spory oraz polemiki. Ostatecznie do tego typu wykroczeń, usytuowanych w kodeksie, zaliczyć należy wykroczenia opisane w przepisach: art. 51 - zakłócanie spokoju, art. 86 (a contrario do art. 177 k.k.) - kolizja drogowa, art. 107 - złośliwe dokuczanie i art. 108 - szczucie psem oraz wykroczenia przeciwko mieniu i tzw. wykroczenia leśne, polne i ogrodowe (szkodnictwo leśne, polne i ogrodowe). Jeszcze trudniej jest wskazać tego typu typizację zlokalizowaną w tzw. ustawach dodatkowych (szczególnych). Wydaje się, że dobrą ilustracją wykroczenia, które może być popełnione na szkodę pokrzywdzonego, jest wykonywanie zabiegu medycznego bez uprawnień (art. 58 ust. 1 ustawy o wykonywaniu zawodu lekarza i lekarza dentysty ${ }^{14}$ ), jeśli przyjmiemy, że przedmiotem ochrony analizowanego czynu jest przede wszystkim ochrona pacjentów przed osobami niewykwalifikowanymi (czasem w piśmiennictwie wskazuje się także na ochronę zawodu przed osobami nieuprawnionymi ${ }^{15}$ ).

Mniej liczny katalog czynów zabronionych (w porównaniu z prawem karnym), będących wykroczeniami, przy popełnianiu których wystąpi figura pokrzywdzonego, nie zwalnia z odpowiedzi na rudymentarne pytanie, czy ogólna zasada upraszczania prawa wykroczeń może powodować osłabienie funkcji ochronnej wobec potencjalnego pokrzywdzonego. Przyznać przy tym należy, że funkcja kompensacyjna w prawie wykroczeń niemal programowo ma o wiele mniejsze znaczenie, jednak w sytuacji popełnienia wykroczenia na szkodę pokrzywdzonego postulaty związane $\mathrm{z}$ tą funkcją aktualizują się $\mathrm{w}$ pełnym zakresie. Również funkcja ochronna nabiera w takich przypadkach rolę wiodącą.

Przegląd różnorodnych instytucji, reguł i zasad odpowiedzialności w prawie wykroczeń, a zwłaszcza ich konfrontacja z analogicznymi przepisami prawa karnego pozwala wyodrębnić dwie grupy regulacji ze wzglę-

14 T.j. Dz.U. 2018, poz. 617 ze zm.

15 R. KĘDzIORA: Odpowiedzialność karna lekarza $w$ zwiq̨zu z wykonywaniem czynności medycznych. Warszawa 2009, Lex, gdzie autorka odnotowuje, iż pod rządami ustawy o zawodzie lekarza z 1950 r. głównym celem była ochrona zawodu lekarza przed osobami zajmującymi się paramedycyną czy medycyną alternatywną. 
du na ich wpływ na pozycję pokrzywdzonego w materialnym prawie wykroczeń. Część rozwiązań przyjętych w materialnym prawie wykroczeń w sposób zdecydowany osłabia tę pozycję, niemniej są i takie rozwiązania, które - przynajmniej formalnie - podnoszą znaczenie pokrzywdzonego w stosunku do pozycji, którą ma w prawie karnym. Wspomniane powyżej regulacje zaprezentowane zostaną w kolejności chronologicznej przyjętej przez kodeks wykroczeń, niezależnie od ich znaczenia - siły wpływu na osłabienie lub wzmocnienie pozycji pokrzywdzonego.

II. Pierwszym rozwiązaniem, przyjętym w kodeksie wykroczeń, osłabiającym pozycję pokrzywdzonego jest eliminacyjny zbieg przepisów i eliminacyjny zbieg wykroczeń. Zgodnie z treścią art. 9 \$ 1 k.w. jeżeli czyn wyczerpuje znamiona wykroczeń określonych $\mathrm{w}$ dwóch lub więcej przepisach ustawy, stosuje się przepis przewidujący najsurowszą karę, co nie stoi na przeszkodzie orzeczeniu środków karnych na podstawie innych naruszonych przepisów. Natomiast jeżeli jednocześnie orzeka się o ukaraniu za dwa lub więcej wykroczeń, wymierza się łącznie karę w granicach zagrożenia określonych w przepisie przewidującym najsurowszą karę, co nie stoi na przeszkodzie orzeczeniu środków karnych na podstawie innych naruszonych przepisów (art. 9 § 2 k.w.). Zarówno w pierwszym, jak i w drugim przypadku karnoprawna ocena czynu oparta jest na jednym przepisie, który nie oddaje pełnej kryminalnej zawartości czynu (\$1) lub kryminalnego obrazu wielu czynów - wykroczeń (\$2). Równocześnie w ten sposób „z pola widzenia” znika też pokrzywdzony, którego dobro zostało naruszone bądź pominiętym fragmentem czynu, bądź pominiętym wykroczeniem. Zasadniczo negatywny wpływ takiego rozwiązania łagodzony jest przez postanowienie, iż można orzec środki karne na podstawie innych naruszonych przepisów, zatem nie ma formalnych przeszkód, aby orzec obowiązek naprawienia szkody na rzecz pokrzywdzonego. Niemniej takie rozwiązanie utrudnia ustalenie zaistnienia wszelkiego rodzaju recydywy, w tym powtórnego pokrzywdzenia przez sprawcę tego samego pokrzywdzonego określonym wykroczeniem.

Realny wpływ na sytuację pokrzywdzonego ma natomiast przyjęta zasada niekaralności usiłowania w prawie wykroczeń, poza szczególnymi sytuacjami, które odrębnie ustawa zaznacza. Są to nieliczne przepisy w kodeksie wykroczeń (np. art. 49a, art. 119 § 2, art. 120 § 2, art. 133 $\S 2$ i inne) oraz - niezmiernie rzadko - w ustawach szczególnych (np. art. 431 ust. 2 ustawy o wychowaniu w trzeźwości i przeciwdziałaniu alkoholizmowi $\left.{ }^{16}\right)$. Zadać należy pytanie, czy lista wykroczeń z niekaralnym usiłowaniem w odpowiedni sposób uwzględniła interesy osób, które były obiektem zamachu obwinionego. W literaturze dość pozytywnie

16 T.j. Dz.U. 2012, poz. 1356 ze zm. 
ocenia się wspomniany katalog, a postulaty wprowadzenia klauzuli karalności za usiłowanie dotyczą ustawy o rybołówstwie śródlądowym ${ }^{17}$, co z perspektywy niniejszego pracowania ma charakter drugorzędny. Wydaje się, że można rozważyć wprowadzenie karalności usiłowania wybranych wykroczeń określanych mianem szkodnictwa leśnego, polnego i ogrodowego. Jestem przekonana, że w ustawach szczególnych brak karalności usiłowania może wydać się szczególnie dotkliwy. Przykładem może być chociażby wspomniana ustawa z 1996 r. o zawodach lekarza i lekarza dentysty i zamieszczony tam przepis art. 58. Przewiduje on dwa rodzaje czynów zabronionych: wykroczenie, polegające na udzielaniu świadczeń zdrowotnych bez uprawnień (ust. 1), oraz przestępstwo, polegające na takim zachowaniu, podejmowanym m.in. w celu osiąnnięcia korzyści majątkowej (ust. 2). Zasady odpowiedzialności przewidziane w kodeksach karnym i wykroczeń powodują, że usiłowanie pierwszego z wymienionych czynów jest niekaralne, drugiego - karalne. Rozróżnienie to nie ma żadnego uzasadnienia merytorycznego i w sposób nieuprawniony osłabia funkcję ochronną prawa wykroczeń. A podkreślić należy, że kwestia kryminalizacji form stadialnych jest o tyle istotna, że karalność usiłowania pełni ważną funkcję prewencyjną, umożliwiając odpowiednim organom reakcję przed naruszeniem dobra prawnego.

Praktyczny wpływ na pozycję pokrzywdzonego mają przyjęte w kodeksie wykroczeń rozwiązania dotyczące form zjawiskowych. Odnosi się to przede wszystkim do współsprawstwa, ale też i sprawstwa poleceniowego, które to postaci w ogóle nie zostały nawet wymienione w kodeksie wykroczeń ${ }^{18}$. Praktyczne osłabienie sytuacji pokrzywdzonego wiąże się z brakiem możliwości nałożenia na wskazane osoby obowiązku naprawienia szkody, co może realnie - wobec słabszej sytuacji ekonomicznej sprawcy wykonawczego - zmniejszyć skuteczność wyegzekwowania tego obowiązku. Problemem też staje się możliwość ukarania sprawców działających wspólnie i w porozumieniu przy tzw. podziale ról (w prawie karnym mówimy o współsprawstwie właściwym) - gdy żaden ze sprawców swoim zachowaniem nie wyczerpuje wszystkich znamion ustawowych typu czynu zabronionego wykroczenia i dopiero łączna ocena ich zachowań pozwala na stwierdzenie realizacji kompletu znamion. W ta-

17 M. Budyn-Kulik. Reforma prawa wykroczeń. T. I. Red. P. Daniluk. Warszawa 2019, s. 184 .

${ }^{18} \mathrm{~W}$ innym miejscu omówiłam, jak istniejące przepisy de facto czynią zachowania wspomnianych podmiotów bezkarnymi - por. O. SITARZ: Materialne prawo wykroczeń. Część ogólna. Warszawa 2015, s. 74 i nast. Zob. także P. Kardas: Podstawy odpowiedzialności za wspótdziałanie w popetnieniu wykroczenia. Kilka uwag o nieistniejacych przepisach. W: W poszukiwaniu prawdy. Ksiegga jubileuszowa ofiarowana Profesorowi Janowi Widackie$m u$. Red. H.E. KubiaK, M. LUBeSKI. Kraków 2018. 
kim przypadku nie ma - w świetle obowiązujących przepisów - możliwości ukarania sprawców, a gdy ich zachowanie godziło bezpośrednio w dobro prawne innej osoby - uznania tej osoby za pokrzywdzonego. Ta wada przyjętego rozwiązania prawnego aktualizować się będzie przede wszystkim w typizacjach kryminalizujących złożone zachowanie, z jakimi mamy do czynienia w przepisach pozakodeksowych, ale dobrą ilustracją problemu może stać się przepis art. $138^{19}$ oraz art. $138 \mathrm{c} \S 1^{20} \mathrm{k}$.w., gdzie podział ról jest całkiem prawdopodobny.

Niezwykle ograniczającym prawa pokrzywdzonego jest przepis art. 28 $\S 2$ k.w., niemający odpowiednika w kodeksie karnym, a który umożliwia orzekanie środka karnego m.in. w postaci obowiązku naprawienia szkody, nawiązki tylko, gdy przepis szczególny tak stanowi. SN wiele razy do tego przepisu nawiązywał. W ciekawym judykacie wskazał, że nie jest możliwe orzeczenie środka karnego, gdy brak szczególnego upoważnienia ustawowego nawet wtedy, gdy sam obwiniony o takie orzeczenie wnosi, a oskarżyciel wniosek ów akceptuje ${ }^{21}$. Jak wskazuje J. Jakubowska-Hara, klauzula obowiązku naprawienia szkody występuje w zaledwie 16 przepisach, a naprawienie szkody może nastąpić w trojaki, ale zawsze ściśle określony sposób: 1) poprzez zapłatę równowartości uszkodzonego, zniszczonego, wyłudzonego, ukradzionego lub przywłaszczonego mienia; 2) poprzez zapłatę równowartości wyrządzonej szkody; 3) poprzez przywrócenie do stanu poprzedniego ${ }^{22}$. Nawiązka na rzecz pokrzywdzonego w kodeksie wykroczeń występuje jeszcze rzadziej.

Podkreślić przy tym należy, że przyjęcie takich rozwiań legislacyjnych znacząco może osłabić motywację sądu do kierowania sprawy do mediacji, a także brania w niej udziału przez strony, skoro zobowiązanie do naprawienia szkody nie może być zamieszczone w wyroku.

J. Jakubowska-Hara zwraca też uwagę na odmienny status obowiązku naprawienia szkody, który w przepisach części ogólnej kodeksu wykroczeń nie został w żaden sposób skonkretyzowany (zresztą jako jedyny środek karny w kodeksie) ${ }^{23}$. Podkreślić należy, że wspomniany obowiązek

19 Art. 138: Kto, zajmując się zawodowo świadczeniem usług, żąda i pobiera za świadczenie zapłatę wyższą od obowiązującej albo umyślnie bez uzasadnionej przyczyny odmawia świadczenia, do którego jest obowiązany, podlega karze grzywny.

${ }^{20}$ Art. $138 \mathrm{c} \S 1$ : Kto w zakresie działalności swojego przedsiębiorstwa zawiera z konsumentem umowę o kredyt konsumencki z rażącym naruszeniem wymagań dotyczących informacji przekazywanych konsumentowi przed zawarciem umowy lub treści umowy albo z pominięciem obowiązku doręczenia jej dokumentu, podlega karze grzywny.

${ }^{21}$ Wyrok SN z dnia 28 sierpnia 2002 r., WK 28/02. OSNKW 11-12/2002, poz. 108.

22 J. Jakubowska-HaRa. W: Z problematyki wiktymologii. Ksiega dedykowana Profesor Ewie Bieńkowskiej. Red. L. Mazowiecka, W. Klaus, A. Tarwacka. Warszawa 2017, s. 422423.

${ }^{23}$ Ibidem, s. 415-416. 
wciąż pozostaje środkiem karnym (w ślad za kodeksem karnym z 1997 r. $\mathrm{w}$ początkowym jego brzmieniu), chociaż $\mathrm{w}$ kodeksie karnym od $2015 \mathrm{r}^{24}$ obowiązek naprawienia szkody $\mathrm{w}$ prawie karnym jest już środkiem kompensacyjnym. Nowelizacja kodeksu karnego z 2015 r. dokonała jeszcze jednego istotnego rozróżnienia. Omawiany środek kompensacyjny w prawie karnym przybiera postać obowiązku naprawienia, w całości lub w części, wyrządzonej przestępstwem szkody lub zadośćuczynienia za doznaną krzywdę (art. $46 \S 1$ k.k.), w prawie wykroczeń jest mowa tylko o obowiązku naprawienia szkody. To oznacza, że krzywda pokrzywdzonego wyrządzona wykroczeniem nie może stać się przedmiotem rozstrzygnięcia sądowego (chyba że przyjmiemy, iż pojęcie szkody w prawie karnym ma inne znaczenie niż w prawie wykroczeń, i w tym ostatnim obejmuje szkodę materialną, jak i niematerialną - majątkową i niemajątkową).

Rozwiązaniem, które radykalnie zmienia na niekorzyść pozycję pokrzywdzonego ( $\mathrm{w}$ stosunku do pozycji pokrzywdzonego w prawie karnym), są przyjęte w kodeksie wykroczeń terminy przedawnienia. W myśl przepisu art. $45 \S 1$ k.w. karalność wykroczenia ustaje, jeżeli od czasu jego popełnienia upłynął rok, a jeżeli w tym okresie wszczęto postępowanie, karalność wykroczenia ustaje z upływem dwóch lat od zakończenia tego okresu.

Kodeks wykroczeń przewiduje więc znacząco krótsze terminy przedawnienia. Oczywiście musi pojawić się pytanie, czy przyjęte rozwiązanie jest zasadne. $\mathrm{Z}$ pewnością nie mogą mieć tu zastosowania argumenty przemawiające generalnie za wprowadzeniem instytucji przedawnienia w postaci przeszkód proceduralnych - zanikanie dowodów, trudności z ich odtworzeniem czy swoistego rodzaju karanie organów ścigania i wymiaru sprawiedliwości za opieszałość. Uzasadnieniem krótkich okresów może więc być tylko mniejsza waga czynów, ale w tym znaczeniu, że upływ czasu szybciej zrywa więź między czynem a społeczną potrzebą ukarania. Również specyficzne funkcje prawa wykroczeń - ochronna i wymuszenie posłuchu dla normy porządkowej, mogą uzasadniać przyjęcie krótszych terminów przedawnienia. Nie można jednak tracić z pola widzenia słusznych interesów pokrzywdzonego, który w krótkim czasie traci możliwość dochodzenia odpowiedzialności $\mathrm{w}$ drodze postępowania $\mathrm{w}$ sprawach o wykroczenia, co jest szczególnie dotkliwe przy czynach przepołowionych, a zwłaszcza przeciwko mieniu.

W literaturze zgłaszane są postulaty dotyczące przedłużenia terminów przedawnienia, gdzie proponuje się wydłużenie czasu na prowadzenie postępowania do dwóch lat, co sprawi, że wydłużeniu powinien ulec też

${ }^{24}$ Ustawa z dnia 20 lutego 2015 r., Dz.U. poz. 396. 
termin przerwany - np. do lat trzech ${ }^{25}$. Postulat ten został zgłoszony, jak się wydaje, przed nowelizacją k.w. z 2017 r. ${ }^{26}$, która - należy domniemywać zaspokaja oczekiwania komentatorów. Jednak w moim przekonaniu terminy przedawnienia niektórych wykroczeń popełnianych na szkodę pokrzywdzonego są dalej zbyt krótkie. Uwaga ta dotyczy przede wszystkim wykroczeń przeciwko mieniu, zwłaszcza gdy wyrządzona szkoda jest niebagatelna w odczuciu społecznym, chociaż wciąż stanowi wykroczenie. Warto bowiem zaznaczyć, że wykroczenie przedawnione jest niekaralne, co oznacza, że postępowania nie wszczyna się, a wszczęte umarza (art. 5 $\S 1$ pkt 4 k.p.w.), natomiast osoba, która odniosła szkodę, nie może zostać uznana za pokrzywdzonego.

Przywołany przepis ustanawia także regułę, że punktem rozpoczęcia biegu przedawnienia jest zawsze czas popełnienia czynu zabronionego, niezależnie od tego, czy wykroczenie ma charakter formalny czy materialny. Jak słusznie zauważa M. Kulik, możliwa jest więc sytuacja, w której wykroczenie zostanie ujawnione po jego przedawnieniu. Zdaniem autora takie uproszenie zasad odpowiedzialności jest niezasadne nawet w przypadku czynów o niższym stopniu społecznej szkodliwości ${ }^{27}$.

III. W prawie wykroczeń znajdują się także rozwiązania, które - przynajmniej formalnie - umacniają pozycję pokrzywdzonego, poszerzając zakres sytuacji (w stosunku do prawa karnego), w których możliwe jest pociągnięcie sprawcy do odpowiedzialności za wykroczenie, a osobie doznającej szkody przydania statusu pokrzywdzonego.

Pierwszym takim rozwiązaniem legislacyjnym jest brak przepisu będącego odpowiednikiem art. 1 § 2 k.k. Zgodnie z jego treścią nie stanowi przestępstwa czyn zabroniony, którego społeczna szkodliwość jest znikoma. Zatem jeżeli w oparciu o kwantyfikatory wymienione w art. 115 $\S 2 \mathrm{k} . \mathrm{k}$. organ prowadzący postępowanie karne dojdzie do przekonania o znikomym stopniu szkodliwości rozpoznawanego czynu, uznać musi, iż czyn ten nie stanowi przestępstwa mimo wypełnienia ustawowych znamion określonej typizacji. W prawie wykroczeń znikomy stopień społecznej szkodliwości nie dekompletuje cech wykroczenia, nie znosi jego bytu. Niezależnie od ocen zasadności przyjęcia takiego rozwiązania i zgłaszanych postulatów de lege ferenda ${ }^{28}$ de lege lata wykroczenia o subminimalnej karygodności nie tracą swojego bytu, a co za tym idzie, osoba do-

${ }^{25}$ M. KuLIK. W: Reforma prawa wykroczeń..., s. 380.

${ }^{26}$ Ustawa z dnia 23 marca 2017 r., Dz.U. poz. 768.

27 M. Kulik. W: Reforma prawa wykroczeń..., s. 375.

${ }^{28}$ K. Olкowicz: Brak przesłanki znikomej społecznej szkodliwości czynu. W: Węzłowe problemy prawa wykroczeń. Czy potrzebna jest reforma?. Red. M. KolEndowsKa-MatejCzuK, V. Vachew. Warszawa 2016; O. Sitarz: Materialne prawo wykroczeń..., s. 48-49; P. DaniluK. W: Reforma prawa wykroczeń. T. I. Red. IDEM. Warszawa 2019, s. 111-116. 
znająca szkody jest pokrzywdzonym, niezależnie od wielkości tej szkody (i innych czynników wpływających na stopień społecznej szkodliwości por.: art. $47 \$ 6 \mathrm{k} . \mathrm{w}$.$) .$

Ciekawą instytucją w prawie wykroczeń jest regulacja zasad odpowiedzialności za wykroczenie popełnione za granicą RP. Zgodnie z przepisem art. $3 \S 1$ k.w. na zasadach określonych w kodeksie wykroczeń odpowiada ten, kto popełnił wykroczenie na terytorium Rzeczypospolitej Polskiej, jak również na polskim statku wodnym lub powietrznym. Natomiast odpowiedzialność za wykroczenie popełnione za granica zachodzi tylko wtedy, gdy przepis szczególny taką odpowiedzialność przewiduje (art. 3 § 2 k.w.). Ilustracją takich szczególnych regulacji (i bodaj jedyną w kodeksie wykroczeń) jest przepis art. 131 k.w. dotyczący wybranych wykroczeń przeciwko mieniu, zgodnie z którym przepisy art. 119, 122 i 124 stosuje się również w razie popełnienia wykroczenia za granicą. Wzmocnienie pozycji pokrzywdzonego wiąże się z brakiem wymogu podwójnej karalności - czyn zarzucany sprawcy nie musi być karalny w miejscu jego popełnienia (tak jak, przy braku odmiennych szczegółowych regulacji, wymaga tego kodeks karny). Zatem niezależnie od stanu prawnego państwa, na terenie którego popełnione zostało wykroczenie opisane w przepisach art. 119, 122 i 124 polskiego kodeksu wykroczeń, osoba doznająca w jego wyniku szkody może być uznana za pokrzywdzonego. Kodeks wykroczeń nie wprowadza też wymogu obywatelstwa ani szczególnego charakteru czynu. Sytuacja sprawcy wykroczenia popełnionego za granicą formalnie może być więc o wiele gorsza niż sprawcy przestępstwa, ale równocześnie oznacza to polepszenie - na gruncie prawa wykroczeń - pozycji pokrzywdzonego.

Rozwiązaniem prowadzącym do poszerzenia pola czynów zabronionych jest zasada ustanowiona w przepisie art. 5 k.w. Stanowi on, że wykroczenie można popełnić zarówno umyślnie, jak i nieumyślnie, chyba że ustawa przewiduje odpowiedzialność tylko za wykroczenie umyślne. Ta ekwiwalencja umyślności i nieumyślności przyjęta jako zasada, od której ustawiane są w drodze ustawy wyjątki, sprawia, że w prawie wykroczeń o wiele częściej mamy do czynienia z czynem zabronionym w sytuacji braku zamiaru jego popełnienia. W prawie karnym nieumyślność zazwyczaj dekompletuje ustawowe znamiona, uniemożliwiając pociągnięcie do odpowiedzialności karnej, w prawie wykroczeń taka sytuacja zdarza się wyjątkowo. Warto jednak podkreślić, że klauzula umyślności może być wyrażona wprost („Kto... umyślnie...” - np. art. 124 § 1 k.w.) lub poprzez użycie znamienia czasownikowego wykluczającego nieumyślność (np. art. 119 \& 1 k.w.). Ten ostatni sposób techniczno-legislacyjny może w konsekwencji wywoływać wątpliwości co do zakresu zabronionego za- 
chowania ${ }^{29}$, a tym samym - statusu pokrzywdzonego. Nie można także przeoczyć faktu, że większość wykroczeń, których konstrukcja pozwala na przyjęcie figury pokrzywdzonego, ma charakter umyślny, co oznacza, że przepis art. $5 \mathrm{k}$.w. nie wpłynął w sposób znaczący na poszerzenie możliwości działania osób pokrzywdzonych $\mathrm{w}$ procesie $\mathrm{w}$ sprawach o wykroczenia.

Swoistym dostrzeżeniem przez ustawodawcę roli i znaczenia pokrzywdzonego, a także uczuleniem na te kwestie organu orzekającego jest treść przepisu art. 33 k.w., a zwłaszcza jego $\S 4$. W tej jednostce redakcyjnej ustawodawca wymienia okoliczności obciążające, które należy uwzględnić. Wśród nich znajduje się „popełnienie wykroczenia na szkodę osoby bezradnej lub osoby, której sprawca powinien okazać szczególne względy". W kodeksie karnym brak jest analogicznego katalogu, jednak jego istnienie w kodeksie wykroczeń ma niewielkie znaczenie praktyczne, zwłaszcza odkąd w sprawach o wykroczenia orzekają sądy dysponujące wysoko wykwalifikowanymi sędziami.

IV. Rekapitulując przeprowadzone rozważania, zwrócić należy uwagę na kilka zagadnień natury ogólnej. Nie ma obecnie wątpliwości, że prawo wykroczeń należy do prawa represyjnego, a z tego wynika dla ustawodawcy i organów orzekających obowiązek przestrzegania standardów właściwych dla prawa karnego. Zatem wszystkie zasady prawa karnego w pełni aktualizują się i w prawie wykroczeń. Należy jednak mieć świadomość, że zasady te dotyczą sprawcy czynu zabronionego. Brak jest ogólnych reguł i zasad co do ukształtowania pozycji pokrzywdzonego, tak w prawie karnym, jak i w prawie wykroczeń. Jedynie analiza poszczególnych przepisów obu kodeksów pozwala na odtworzenie statusu pokrzywdzonego i skonfrontowanie go na płaszczyźnie dwóch omawianych reżimów odpowiedzialności.

Konfrontacja ta ujawnia daleko idące odrębności w zakresie pozycji pokrzywdzonego $\mathrm{w}$ regulacjach materialnych prawa wykroczeń. Waga tych odrębności jest różna, ale wydaje się, że w praktyce regulacje ograniczające zakres występowania figury pokrzywdzonego mają silniejsze znaczenie - realnie wpływają na zmniejszenie uprawnień osoby, której została wyrządzona szkoda. Do takich regulacji zaliczyć należy przede wszystkim przepisy odnoszące się do możliwości orzekania środków karnych o charakterze kompensacyjnym oraz przepisy określające terminy przedawnienia (obok innych przepisów wcześniej również omówionych). Oczywiście wskazane odrębności w stosunku do przestępstw są w dużej mierze uzasadnione charakterem samych wykroczeń. I chodzi nie tylko

${ }_{29}$ Por. podnoszone wątpliwości przykładowo odnośnie do przepisu art. $116 \S 1$ k.w. O. SITARz: Materialne prawo wykroczeń..., s. 60. 
o wagę czynu, ale też konstrukcję czynu wprowadzającego karalność na (bardzo) dalekim przedpolu naruszenia dobra prawnego. Niemniej odrębności takie są jednak całkowicie bezzasadne, gdy wykroczenie jest bardzo silnie istotowo związane z przestępstwem, a ich rozgraniczenie jest wręcz sztuczne. W takich przypadkach zarówno wykroczenia, jak i przestępstwa są czynami z naruszenia dobra prawnego, a różnica sprowadza się do wielkości szkody. Chodzi przede wszystkim o czyny zabronione przeciwko mieniu (chociaż pomieszczone nie tylko w rozdziale XIV kodeksu wykroczeń). Podkreślić należy, że przyjęty dualny model odpowiedzialności w tym zakresie narusza zasadę równości, poręczoną przepisem art. 32 ust. 1 Konstytucji ${ }^{30}$. Bowiem różnica w pokrzywdzeniu kradzieża na szkodę 450 zł i 550 zł jest na tyle niewielka, że odmienne traktowanie pokrzywdzonych (obok oczywiście sprawców czynów) jest naruszeniem tej zasady, zgodnie z którą wszystkie podmioty prawa charakteryzujące się daną cechą istotną w równym stopniu powinny być traktowane równo, według jednolitej miary, bez zróżnicowań dyskryminujących lub faworyzujących ${ }^{31}$. Jednocześnie zasada ta zakłada odmienne traktowanie tych podmiotów, które nie posiadają wspólnej cechy istotnej. Na marginesie odnotować trzeba, że teza ta może stanowić kolejny argument za zniesieniem niektórych czynów przepołowionych (bitypów) ${ }^{32}$.

Przeprowadzona analiza uwidoczniła konieczność rozważenia wprowadzenia pewnych zmian w kodeksie wykroczeń. Podkreślić jednak należy, że ich uzasadnieniem jest nie tyle ujednolicenie kodeksu karnego i kodeksu wykroczeń, ponieważ taki cel jako sam w sobie nie może uzasadniać nowelizacji. Ewentualne zmiany podyktowane być winny postulatem wzmocnienia pozycji pokrzywdzonego i poszanowania zasady równości.

$\mathrm{Na}$ zakończenie rozważań o pozycji pokrzywdzonego trudno nie wspomnieć o niezwykle istotnej instytucji, co prawda o charakterze procesowym, która ma jednak silny wpływ na poszanowanie interesów pokrzywdzonego na płaszczyźnie prawnomaterialnej. Na mocy bowiem art. 8 k.p.w. w postępowaniu w sprawach o wykroczenia stosuje się m.in. przepis art. 23a k.p.k. To oznacza możliwość skierowania sprawy „wykroczeniowej” do mediacji. Co prawda analizowany przepis art. 28 § 2 k.w. nieco umniejsza jej znaczenie, niemniej zgodnie z przepisem art. $33 \S 3 \mathrm{k} . \mathrm{w}$. przyczynienie się lub staranie się sprawcy o przyczynienie

${ }^{30}$ Wszyscy są wobec prawa równi. Wszyscy mają prawo do równego traktowania przez władze publiczne.

31 Por. stanowisko RPO opublikowane na stronie internetowej. Źródło: https:// www.rpo.gov.pl/pl/kategoria-konstytucyjna/art-32-rownosc-i-zakaz-dyskryminacji [dostęp: 12.03.2019].

32 O. Sitarz: Kilka refleksji na temat likwidacji tzw. czynów przepołowionych. $\mathrm{PiP} 2006$, nr 11. 
się do usunięcia szkodliwych następstw swego czynu stanowi okoliczność łagodzącą, którą organ orzekający winien uwzględnić. Ponadto organ ten winien wziąć pod uwagę m.in. zachowanie sprawcy po popełnieniu wykroczenia. Nie można wykluczyć, chociaż brak takiego przepisu, że na skutek pozytywnie zakończonej mediacji sąd zastosuje warunkowe zawieszenia wykonania kary aresztu ${ }^{33}$, jeżeli szkoda została w całości naprawiona (art. $42 \S 3$ k.w.), lub zastosuje nadzwyczajne złagodzenie kary albo odstąpi od jej wymierzenia (art. 39 § $1 \mathrm{k} . \mathrm{w}$.). Z perspektywy pokrzywdzonego to ostatnie rozwiązanie ma o tyle znaczenie, że w myśl art. 39 § 4 k.w. w razie odstąpienia od wymierzenia kary można zastosować w stosunku do sprawcy środek oddziaływania społecznego, mający na celu przywrócenie naruszonego porządku prawnego lub naprawienie wyrządzonej krzywdy, polegający zwłaszcza na przeproszeniu pokrzywdzonego, uroczystym zapewnieniu niepopełniania więcej takiego czynu albo zobowiązaniu sprawcy do przywrócenia stanu poprzedniego.

\section{Bibliografia}

\section{Literatura}

BudYN-KuliK M. W: Reforma prawa wykroczeń. T. I. Red. P. DANILUK. Warszawa 2019.

DANILUK P. W: Reforma prawa wykroczeń. T. I. Red. IDEM. Warszawa 2019.

DUDKA K.: Skuteczność instrumentów ochrony praw pokrzywdzonego w postępowaniu przygotowawczym $w$ świetle badań empirycznych. Lublin 2006.

GostyŃski Z., Stefański R.A. W: Kodeks Postępowania Karnego. Komentarz. T. I. Red. Z. GostyŃski. Warszawa 2003.

JakUbowsKa-HaRA J. W: Reforma prawa wykroczeń. T. I. Red. P. Daniluk. Warszawa 2019.

JakUbowsKa-HaRa J. W: Z problematyki wiktymologii. Ksiegga dedykowana Profesor Ewie Bieńkowskiej. Red. L. Mazowiecka, W. Klaus, A. TarWacka. Warszawa 2017.

KaRDas P.: Podstawy odpowiedzialności za wspótdziatanie w popetnieniu wykroczenia. Kilka uwag o nieistniejacych przepisach. W: W poszukiwaniu prawdy. Księga jubileuszowa ofiarowana Profesorowi Janowi Widackiemu. Red. H.E. KuBIAK, M. LUBELSKI. Kraków 2018.

KĘDZIORA R.: Odpowiedzialność karna lekarza $w$ związku z wykonywaniem czynności medycznych. Warszawa 2009.

KotowsKi W., KuRZępA B.: Kodeks postępowania $w$ sprawach o wykroczenia. Komentarz. Warszawa 2016.

${ }^{33}$ Nie tracąc z pola widzenia wszystkich mankamentów tego rozwiązania i jego mizerne znaczenie w praktyce - por. J. JAKUBOwsKa-HARA. W: Reforma prawa wykroczeń. T. I. Red. P. DaniluK. Warszawa 2019, s. 331-339. 
KulEsZA C.: Ewolucja uprawnień pokrzywdzonego $w$ polskim prawie karnym. W: Z problematyki wiktymologii. Księga dedykowana Profesor Ewie Bieńkowskiej. Red. L. Mazowiecka, W. Klaus, A. Tarwacka. Warszawa 2017.

KulEsza C.: Rola pokrzywdzonego $w$ procesie karnym $w$ świetle ustawodawstwa i praktyki wybranych krajów zachodnich. Białystok 1995.

Kulik M. W: Reforma prawa wykroczeń. T. I. Red. P. DaniluK. Warszawa 2019.

LeWIŃski J.: Pokrzywdzony $w$ postępowaniu $w$ sprawach o wykroczenia. Pal. 2003, nr 11-12.

Mамак K. W: Kodeks postępowania w sprawach o wykroczenie. Komentarz. Red. A. SAKowicz. Warszawa 2018.

Olкоwicz K.: Brak przesłanki znikomej społecznej szkodliwości czynu. W: Węzłowe problemy prawa wykroczeń. Czy potrzebna jest reforma?. Red. M. KolENDOWSKA-MatejczuK, V. Vachew. Warszawa 2016.

SITARz O.: Kilka refleksji na temat likwidacji tzw. czynów przepołowionych. PiP 2006, nr 11.

Sitarz O.: Materialne prawo wykroczeń. Część ogólna. Warszawa 2015.

STACHOWIAK S.: Podstawowe uprawnienia pokrzywdzonego w ujęciu nowego kodeksu postępowania $w$ sprawach o wykroczenia. PPol. 2002, nr 3-4.

ŚwIECKI D.: Metodyka pracy sędziego w sprawach o wykroczenia. Warszawa 2012.

Wójcicka B.: Pozycja pokrzywdzonego w nowym kodeksie postępowania $w$ sprawach o wykroczenia. PiP 2001, nr 10.

\section{Orzecznictwo}

Uchwała SN Izby Karnej oraz Wojskowej z dnia 26 listopada 1976 r., VI KZP 11/75. OSNKW 1/1977, LEX nr 19212.

Uchwała SN z dnia 15 września 1999 r., I KZP 26/99. OSMKW 11-12/1999, poz. 69.

Uchwała SN z dnia 21 października 2003 r., I KZP 29/03. OSNKW 11-12/2003, poz. 94.

Postanowienie SN z dnia 23 kwietnia 2002 r., I KZP 10/02. PiP 2002, nr 7-8, poz. 1.

Wyrok SN z dnia 28 sierpnia 2002 r., WK 28/02. OSNKW 11-12/2002, poz. 108. 